\title{
When Poetry Fell in Love with Philosophy: Robert Bringhurst and Sophocles' Meditation on Human Nature
}

\author{
Leonor María Martínez Serrano \\ UnIVERSIDAD DE CóRdoba \\ 152masel@uco.es
}

Recibido: 14/11/2017

Aceptado: 28/06/2018

\begin{abstract}
:
This article aims at shedding light on a poem entitled «Of the Snaring of Birds», one of the twelve pieces included in Canadian poet Robert Bringhurst's The Old in Their Knowing (2005). Dedicated to German philosopher Martin Heidegger, «Of the Snaring of Birds» turns out to be a most eloquent version, not a faithful rendering, of the original Greek text by Sophocles, as well as a probing meditation on what makes us truly human. Bringhurst finds literary sustenance in a 2,400-year-old text and makes it brand new for 21st-century readers who still care to listen to the insights of our ancestors.
\end{abstract}

KEYWORDS: Robert Bringhurst, Sophocles, Antigone, poetry, literary translation, lyric philosophy.

Cuando la poesía se enamoró de la filosofía: meditación de Robert Bringhurst y Sófocles acerca de la condición humana

\section{RESUMEN:}

Este artículo trata de elucidar un poema titulado «Of the Snaring of Birds», incluido en la secuencia poética del autor canadiense Robert Bringhurst titulada The Old in 
Their Knowing (2005). Dedicado al filósofo alemán Martin Heidegger, «Of the Snaring of Birds» se desvela como una elocuente versión, no como traducción fiel y literal, del texto griego original de Sófocles, y encierra una profunda meditación sobre lo que nos hace verdaderamente humanos. Bringhurst encuentra la inspiración literaria en un texto de más de 2400 años y lo renueva para aquellos lectores del siglo XXI que aún están ávidos por escuchar las intuiciones y hallazgos de nuestros ancestros.

PALA BRAS CLAVE: Robert Bringhurst, Sófocles, Antígona, poesía, traducción literaria, filosofía lírica.

\section{Back to the Splendour of Classical Greece}

Ancient Greece still remains the genuine cradle of Western culture. In the 21st century, Canadian poet, linguist, philosopher, translator, cultural historian and typographer Robert Bringhurst still finds literary nourishment in the ancient Greek masters. The Old in Their Knowing (2005) is possibly one of his most fascinating poetic achievements, not just because it brings together poetry, philosophy and translation, but also because it accomplishes much which is new in the context of Canadian literature. The twelve poems that make up the entire sequence are philosophical treatises in miniature drawing on the extant fragments of the Pre-Socratics and other Greek authors like Sophocles or Pindar. They illustrate Ezra Pound's dictum that Dichtung $=$ condensare as propounded in his ABC of Reading (1934). In actual fact, Bringhurst manages to condense the essence of W. K. C. Guthrie's monumental A History of Greek Philosophy (more specifically volume 2, The Presocratic Tradition from Parmenides to Democritus) into a series of poems of rare beauty and perfection with the utmost linguistic economy, each poem exploring the thought of a Pre-Socratic philosopher. These poems on the Pre-Socratics remain a powerful homage to philosophers, scientists and poets like Pythagoras, Herakleitos, Empedokles, Parmenides or Democritus, whose sharp minds looked at the awe-inspiring world with a new form of intellectual alertness in the very cradle of Western Philosophy. What the twelve poems in this sequence embody is a sort of archaeology of human 
knowledge by one single man concerned with rescuing from the past the most precious insights into reality gained by our ancestors.

This article focuses not on those poems in The Old in Their Knowing exploring the thought of the Pre-Socratics, but rather on one particular poem entitled "Of the Snaring of Birds", which was inspired by a powerful chorus in Sophocles' Antigone. More specifically, it seeks to shed light on its meaning and structure, as well as on its relationship to Sophocles' chorus as one of the oldest meditations on humanity in the constellation of texts making up the Western canon. Martin Heidegger's enlightening reading of the Greek poem in his Introduction to Metaphysics will guide the whole exegetical exercise, since, in his close reading of the text, the philosopher interprets the chorus as being an eloquent voicing of the ancient Greek conception of man as the strangest thing on Earth. In the process, the article seeks to elucidate what the practice of translation represents for a 21st-century poet like Bringhurst, an erudite poet who reads from several modern and classical languages and has translated various texts from a number of literary traditions during the last four decades.

By focusing on a 21st-century poet who still translates from the Greco-Roman tradition, this article seeks to demonstrate that what is found in literary translation far exceeds what is lost in spite of the passage of time and linguistic barriers. After all, every natural language has its own limitations and its own resources, and translation as a cultural practice goes beyond the abyss that might separate different worldviews and literary traditions. From the very outset of his literary career, translation offered Bringhurst innumerable opportunities to study prosody and the music of poetry, ${ }^{1}$ to practise a sort of intellectual gymnastics that

1 In the essay «Breathing Through the Feet: An Autobiographical Meditation», collected in Pieces of Map, Pieces of Music, Bringhurst himself confesses this fascination with the material side inherent in the writing of poetry: «Pound himself touched another American bent in me too, and that was my prolonged fascination 
enriched his own writing and to find his own poetic voice. Over the last four decades, he has translated mostly from classical Greek and classical Arabic, from modern languages like German or French, but he has also translated myths and poetic narratives from classical Haida, one of the hundreds of languages native to North America, spoken in Haida Gwaii or Queen Charlotte Islands, off the West Coast of Canada. As Bringhurst points out in an interview with Thérèse Rigaud, «My loyalty as an artist is to individual humans and to the species as a whole, but not to much of anything in between. My loyalty as a translator is to the individual authors and the texts that I'm translating, and to everyone who may be going to read them» $(2002,11)$.

The practice of translation has also given Bringhurst the chance to form his own multilingual literary canon, his own vademecum of indispensable authors across different traditions and spatio-temporal boundaries: the Upanishads stand side by side with Sophocles and Pindar, Pre-Socratics like Herakleitos, Empedokles and Parmenides, Plato and Aristotle, Oriental sages like Saraha, Dogen or Nagarjuna, contemporary poets like R. M. Rilke, Paul Valéry, T. S. Eliot, Ezra Pound, Pablo Neruda or García Lorca, thinkers like Heidegger and Levinas, and the Haida mythtellers Ghandl and Skaay. Like the High Modernists before him, Pound and Eliot in particular, Bringhurst feels that if he is to make a pertinent and lasting contribution to literature, he must have a solid, thorough knowledge of the best that has been accomplished by his literary ancestors. When confronted with his poems, translations and essays, the alert reader cannot but notice that Bringhurst finds sustaining nourishment in the intellectual legacy left us by our ancestors, no matter whether Western or Eastern, and regardless of the language those works are embodied in, for he is also a fluent polyglot and a lover of human languages.

with craftsmanship and technique, with inward mechanics and outward physical forms. With Pound's example before me, I spent years on the study of metrics. [...] I studied prosodic systems and speech sounds, the acoustic as well as syntactic shaping of language» $(1986,105)$. 
Originally published in Bringhurst's Cadastre (1973) under the title «Strophe from Sophocles», the poem under scrutiny was a translation of the first stanza in a chorus from the Greek playwright's well-known tragedy Antigone - a chorus which constitutes an extended meditation on human beings' nature and omnipotent domination over all creatures on Earth. The dedication preceding the poem reads thus: «from the Antigone of Sophocles, a version in memory of Martin Heidegger, 1889-1977». In fact, «Of the Snaring of Birds» is a most eloquent version, not a faithful rendering, of the original text, conceived as a homage to Heidegger, a lover of all things ancient and Greek. In the Notations at the end of Cadastre, Bringhurst rightly informs the reader that «The Sophocles doesn't derive from Heidegger's reading of the passage, but neither does it seem to replace Heidegger's reading» $(1973,80)$. With these words, the poet appears to suggest that readers should bear in mind Heidegger's exegetical study of Sophocles' poem in his Einführung in die Metaphysik or Introduction to Metaphysics (chapter IV, section 3), in the hope that some sort of stereoscopy might be achieved if his translation is read in conjunction with the original Greek text and the German philosopher's lucid interpretation of Sophocles' words. Later on, this original translation of the first strophe was further expanded to include the whole chorus from Antigone (lines 332-375) in the poem re-titled «Of the Snaring of Birds», included for the first time in Bringhurst's twelve-poem sequence called «The Old in Their Knowing» in The Beauty of the Weapons (1982). For a long time, «Of the Snaring of Birds» was a work in progress that the author revisited, expanded and refined in every new textual reincarnation of the sequence, which was reprinted in The Calling: Selected Poems 1970-1995 (1995), once again with the author's latest emendations in The Old in Their Knowing (2005) and, finally, in his elegantly printed Selected Poems (2009).

In what follows, Bringhurst's rendering of Sophocles' chorus from classical Greek into English in «Of the Snaring of Birds» is analysed in detail to highlight the simple fact that what he found 
in Sophocles' chorus was not just a translation challenge to test his command of English as a medium of literary creativity, but also one of the earliest and most probing meditations on humankind in the Western tradition. In Sophocles' words he probably found a jewel-like text that had to be revisited and translated again into English to the benefit of postmodern readers. The ancient Greek playwright delineates the fundamental traits of the human condition, and those attributes reveal themselves to be timeless and unchangeable universals. In actual fact, Sophocles' Antigone is a universal classic capable of talking to contemporary readers, precisely because humankind remains the same in spite of changes in the outward appearance of human societies. Sophocles himself meets all the requirements identified by T. S. Eliot in «What is a Classic?» (1944) to be considered a classic:

A classic can only occur when a civilization is mature; when a language and a literature are mature; and it must be the work of a mature mind. It is the importance of that civilization and of that language, as well as the comprehensiveness of the mind of the individual poet, which gives the universality. [...] A mature literature $[\ldots]$ has a history behind it: a history, that is not merely a chronicle, an accumulation of manuscripts and writings of this kind and that, but an ordered though unconscious progress of a language to realize its own potentialities within its own limitations. $(1956,55-56)$

After 2,400 years, Sophocles' thinking and singing keep on shedding light on human nature. As Canadian critic Northrop Frye puts it in an enlightening essay entitled «Verticals of Adam», included in The Educated Imagination, literature is a construct of the human imagination and «the constructs of the imagination tell us things about human life that we don't get in any other way» $(1964,125)$. The human imagination can also unveil the hidden pattern beneath the unstoppable flux of reality, for «a great work of literature is also a place in which the whole 
cultural history of the nation that produced it comes into focus» (1964, 123). Because Bringhurst is sensitive to the fact that Antigone is one of the epitomes of Sophocles' and classical Greece's maturity, he probably felt it was his mission to render this handful of memorable words into contemporary English. Sophocles is clearly one of the ancestors he wishes to emulate, as well as a paradigmatic example of the kind of literature Bringhurst wishes to make a relevant contribution to: a philosophical poetry or lyric philosophy concerned with deep thinking, one in which it is hard to draw a clear-cut boundary between poetry and philosophy.

\section{Sophocles' Ultimate Elegance}

Sophocles must have been an endless source of inspiration for Robert Bringhurst for a number of reasons, and not just because he is one of the giants towering high on the horizon of the Western canon. Sophocles evolved for his plays a plain style that was very different from the magniloquence of his senior contemporary Aeschylus. This simplicity and elegance of language, along with an astonishing profundity of thought, must have been certainly appealing to the Canadian poet. Ezra Pound, the acknowledged master and ubiquitous presence in Bringhurst's oeuvre, may have put the poet on the right trail. Pound himself gave thought to Sophocles as well: he translated the Greek playwright's play Women of Trachis into English. Most importantly, Pound uses the expression «Sophoclean light» in his poem «Ité» ${ }^{2}$ to criticise the misty derivativeness and self-indulgent subjectivity of English poetry since the 1890s up to his day (1915, the year of publication of Lustra, where «Ité» is included). Sophocles is thus presented as symbolising an objective, hard kind of poetry, one endowed with

2 «Ité» (the Latin 'ite' means go) reads as follows: «Go, my songs, seek your praise from the young and from the intolerant, / Move among the lovers of perfection alone. / Seek ever to stand in the hard Sophoclean light / And take your wounds from it gladly.» The phrase 'Sophoclean light' «may derive from 'lumen siccum' (dry light), of the medieval scholastics» $(1969,156)$, writes K. K. Ruthven in the notes on the Personae poems in A Guide to Ezra Pound's Personae (1926). 
a firm grasp of reality, as opposed to sentimental and abstract poetry. However, the early version of the classical Greek text in «Strophe from Sophocles» as published in Cadastre was but the beginning of a long process whereby Bringhurst would try to come to terms with the ancient poem. Thus, «Strophe from Sophocles» was to be subsequently modified and expanded into the poem entitled «Of the Snaring of Birds», which underwent a significant metamorphosis in every new textual reincarnation. In the Notations at the end of Cadastre, Bringhurst informs readers that

The Sophocles doesn't derive from Heidegger's reading of the passage, but neither does it seem to replace Heidegger's reading. (Similarly, Morrison's drawing of Poseidon in his Armor isn't, so far as I know, based on Leonardo's Neptune with his Horses; but the two can be looked at together nevertheless to achieve a degree of stereoscopy.) $(1973,80)$

With these words, the poet appears to suggest that, in order to achieve a better understanding of the chorus, readers should bear in mind Heidegger's penetrating reading of Sophocles' poem in his Einführung in die Metaphysik. In his exegesis, Heidegger dwells on every strophe and antistrophe in Sophocles' chorus with an intellectual alertness that betrays his claritas of mind. Bringhurst goes back to the original Greek as proffered by Sophocles in 442 or $441 \mathrm{BCE}$, but he cannot simply ignore the German philosopher's interpretation, for it towers high among the seminal texts of twentieth-century Western philosophy. In a review of Bringhurst's Tzuhalem's Mountain and The Beauty of the Weapons published in The Reader, Charles Lillard observes:

Fittingly, these lines, from a version of Sophocles's Antigone, are dedicated to the memory of the German philosopher Martin Heidegger. «Fittingly» for in his Poetry, Language, Thought Heidegger suggests «The poet need not think; the thinker need not create poetry; but to be a poet of the first rank there is a thinking that the poet 
must accomplish, a thinking which has all the purity and thickness and solidity of poetry, and whose saying is poetry». $(1983,2)$

The German philosopher's influence on Bringhurst's thinking and conception of poetry is crucial, and so it is only natural that «Of the Snaring of Birds», a deep meditation on humankind, should be a homage to this fundamental thinker. For both Heidegger and Bringhurst, poetry and philosophy belong together: they are forms of paying attention to what is, or, to put it differently, they are knowledge «freed from the agenda of possession and control» (Bringhurst, 2007, 15). In some of his seminal essays, Bringhurst has meditated on the nature of poetry, being and knowing with a penetrating lucidity reminiscent of Heidegger's. Poetry is the purest form of knowing, he claims. When one gives up all hope of controlling or possessing the world, the real thinking which poetry is comes to happen. But poetry is only one among different forms of paying attention to what is. Like philosophy or science, poetry stems from wonder and curiosity in the face of the inexhaustible exuberance of reality, or, to put it differently, it is one way of responding and speaking to the world. If we look at the etymology of the words 'poetry', 'poem' and 'poet', we learn that all three are Greek-origin words com-

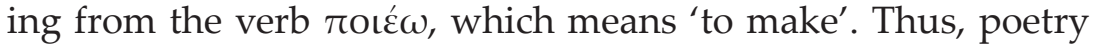

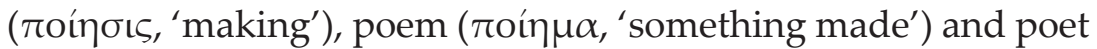

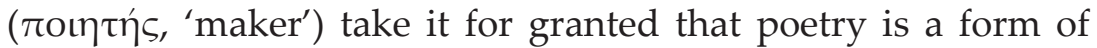
handiwork, of making. Of course, poetry precedes language and even human beings. Poetry takes precedence. Bringhurst writes in his essay «Everywhere Being Is Dancing»: «Poets make things. True enough. But they don't make poetry, or they don't make it from nothing. Poetry is present to begin with; it is there, and poets answer it if they can. The poem is the trace of the poet's joining in knowing» $(2007,18)$.

In this respect, Bringhurst's poetry (or lyric philosophy) is inextricably linked to Heidegger's sustained philosophical meditation on the relationship between language, poetry and think- 
ing. A profound lover of Pre-Socratic philosophers, Heidegger resorted to the poetry of Friedrich Hölderlin (who composed a poem entitled Empedokles himself, drawing on the life and thought of the ancient Greek philosopher) and other German poets to illustrate the relationship holding between language and poetry. In Heidegger's conceptualisation, poetry is a form of Ur-Sprache or ancestral language that unveils the essence of things. Things are the places where the truth of being happens, but it is in the work of art, particularly in the work of poetry, where such disclosedness is most compellingly experienced. Actually, in Heidegger's own well-known formulation, die Sprache spricht, language speaks, and in speaking it sheds light on what is epistemologically in the dark. Most importantly, in Unterwegs zur Sprache, the philosopher suggests that human beings' ultimate, essential home is language: «das Sein istet, die Welt weltet, die Zeit zeitigt, das Nicht nichtet, das Ding dingt, das Ereignis ereignet, die Sprache spricht. [...] Die Sprache ist das Haus des Seins» $(1959,10)$.

But let us turn to the original text in Antigone and the vital circumstances that accompanied the Greek man who composed such a masterpiece amid the splendour of classical Athens, at the heights of its creative powers and intellectual maturity. Sophocles was born ca. $496 \mathrm{BCE}$ at Colonus, a village outside the walls of Athens, and he died in 406 BCE in Athens, the cultural centre of classical Greece. He is one of the classical Athens's three great tragic playwrights along with Aeschylus and Euripides. Few facts are known about his life, but whatever details are known about it are worth recording: knowing the man will give us a clue to understand why Bringhurst should have decided to translate a chorus from one of his most accomplished plays. Sophocles came from a wealthy family, and he was highly educated, noted for his impressive beauty of physique, athletic prowess, and outstanding artistic talents. Endowed with a sense of social commitment, he participated actively in civic life affairs in the Greek polis. He won his first victory at the Dionysian dramatic festival 
in $468 \mathrm{BCE}$, defeating the great Aeschylus in the process and beginning a career of unparalleled success and longevity. In total, he wrote 123 dramas for the festivals, of which only seven works of maturity have survived in their entirety: Ajax is generally regarded as the earliest of the extant plays; Antigone was first performed in 442 or 441 BCE; Philoctetes was first performed in 409 BCE; and Oedipus at Colonus was produced after his death by his grandson.

Needless to say, Sophocles was a superb artist and many of his plays are masterpieces of construction. He has been universally admired for his command of language, for his mastery of form and diction, and for the sympathy and vividness with which he delineates his characters. He is also credited with the introduction of a third actor in the dramatic performance onstage, which enabled him to increase the number of his characters and extend the scope and complexity of the dramatic conflict. Thus, the typical Sophoclean drama presents a few characters, impressive in their determination and possessing a few strongly drawn qualities or faults that combine with a particular set of circumstances to lead them inevitably to a tragic fate. Apart from being a magnificent craftsman, this master playwright was concerned with investigating the tragic dimension inherent in the human condition. To Sophocles, human beings live for the most part in dark ignorance because they are cut off from the gods - those permanent, unchanging forces of reality. He presents truth in collision with ignorance, delusion, and folly. Ultimately, it is through pain, suffering, and endurance of tragic crisis that people get into contact with the universal order of things and gain some sort of knowledge of themselves. In this respect, Antigone is a play about the conflicting obligations of civic versus personal loyalties and religious mores. Antigone follows the dictates of her conscience, against all sorts of conventional rules and norms, intangible bondage and tyranny, as represented by Creon's edict that no one in the polis is to bury the body of Polinices, a traitor to the city and Antigone's brother. 


\section{Humans' Dominion over the Sea and the Earth}

The chorus from Antigone (lines 332-375) 3 Bringhurst chooses to translate is one of the summits or climactic moments in the unfolding of the tragedy itself. The poet must have admired the clarity, the precision, the command of language on the part of the Greek master in what turns out to be the most moving meditation about the human condition in the whole play. Whereas Sophocles' chorus is an extended meditation on humans' nature - on their virtues and omnipotent domination over all creatures on Earth -, Bringhurst's early «Strophe from Sophocles» is just a miniature meditation that focuses on humans' relationship with two fundamental natural forces: the sea and Mother Earth. The original miniature meditation published as «Strophe from Sophocles» opens like this:

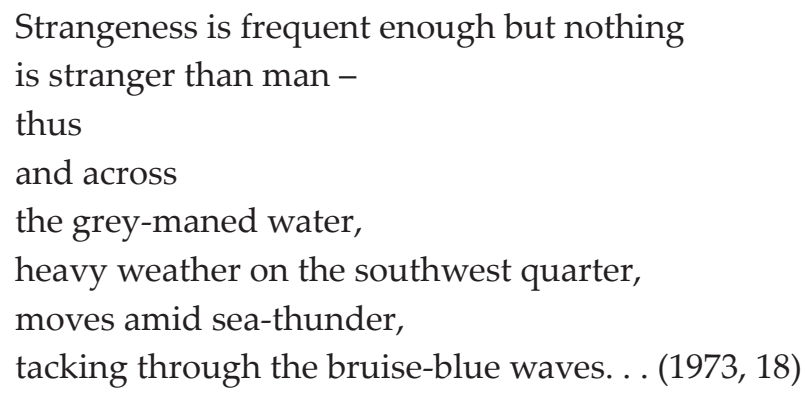

In its later textual incarnation in «Of the Snaring of Birds», consisting of four stanzas (or of two strophes and their corresponding antistrophes), this stanza is extensively revised and reads as follows in The Old in Their Knowing edition:

Strangeness is frequent enough, but nothing is ever as strange as a man is.

3 See Antigone. The Women of Trachis. Philoctetes. Oedipus at Colonus, edited and translated by Hugh Lloyd-Jones, p. 35 and p. 37, for a plain prose English translation of the original Greek text. The original Greek text can be found in The Antigone of Sophocles, edited with introduction and notes by Richard C. Jebb. 


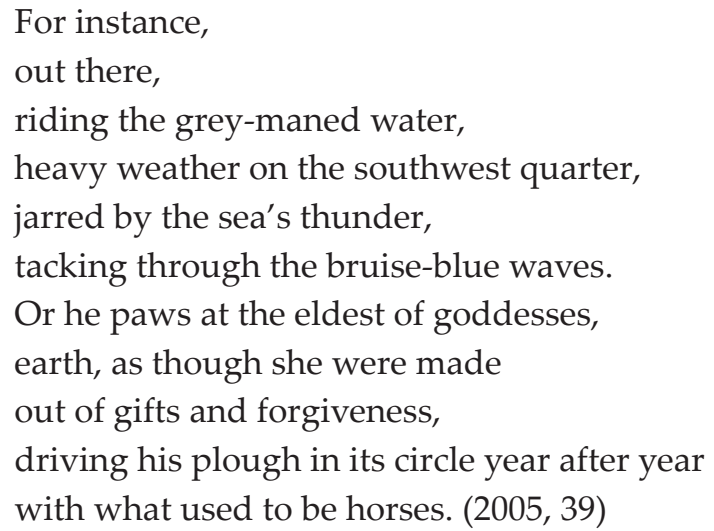

The starting point of Sophocles' meditation is straightforward enough: man is a strange or uncanny creature, stranger than any

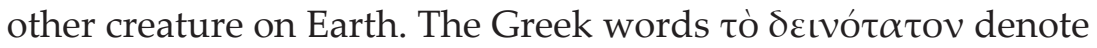
not just one more attribute of humankind, but the very essence or irreducible core of humanity: man is the uncanniest or strangest thing on Earth, which, according to Heidegger, is the Greek definition of what it means to be human. ${ }^{4}$ Endowed with intelligence and sagacity, man manages to control the implacable forces of nature to his own satisfaction and benefit. In the Greek framework of perception, the world is a place pervaded by the presence of gods and goddesses, who more often than not interfere in human affairs. But the world is out there for humans to conquer with all the strength, might and sagacity they are capable of. The

4 As Heidegger points out in his Einführung in die Metaphysik, «Dieses Wort, daß

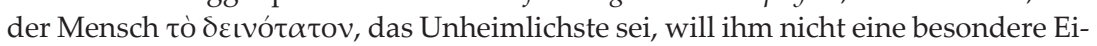
genschaft zusprechen, gleich als sei der Mensch sonst noch etwas anderes; vielmehr sagt das Wort: das Unheimlichste zu sein, ist der Grundzug des Menschenwesens, in den je und immer alle anderen Züge eingezeichnet werden müssen. Der Spruch: »der Mensch ist das Unheimlichste«, gibt die eigentliche griechische Defitinion des Menschen» $(1983,160)$. [«This word, that the human is to deinotaton, the uncanniest, does not intend to assign the human a particular property, as if the human were something else in addition; instead the word says: to be the uncanniest is the basic trait of the human essence, into which every other trait must always be drawn. The saying «the human being is the uncanniest» provides the authentic Greek definition of humanity» $(2000,161)$.] 
"grey-maned water», which is the embodiment of Poseidon to the Greeks' mythopoeic mind, awakens humans' sense of grandeur in the face of the sublime and of the unknown. That human beings are vulnerable, devoid of warmth or protection when they arrive on Earth, is out of the question. That the ocean is stronger than all human beings is also out of the question, yet it remains a challenge for humans to sail on it in vessels they have devised with their knowledge of engineering and mechanics (techné), which render the world manageable to a certain extent. Hence the sea with its vast expanses of water offers no obstacles at all in spite of bad weather conditions, as humans are reckless in their determination to ride the «bruise-blue waves» comfortably in the bosom of their vessels, regardless of whether they are aided by favourable winds or not.

The two primordial divine entities in Greek cosmogony are Heaven (Uranus) and Mother Earth (Gea). Out of their marriage sprang everything that comprises the cosmos. No mention is made here of Heaven, but rather of the Earth in its entirety, which consists of water and solid earth. Both the sea and the earth are mentioned as uncanny forces of the natural world. The word 'sea' is pronounced as if for the very first time, as it represents an elemental force in nature, wild and impenetrable in spite of humankind's compulsion to take dominion over it. As for Earth, it is «the eldest of goddesses» (Bringhurst, 2005, 39), the first mother of mothers. Out of a proverbial generosity, she has sustained innumerable generations of humans, has nourished them and given them all they need to lead a comfortable existence. For their part, humans make use of whatever available resources they have (the plough and the brute force of horses) to till it and cultivate it, so as to make it yield nourishment to appease their hunger and thirst. After all, it is the survival of the human species that is at stake. There is no respite for Mother Earth, as some sort of violence is being exerted on her time and again. And yet, she still gives human beings generously whatever they demand of her. According to Heidegger, Mother Earth 
is indeed a primordial goddess upon which the human being exerts a form of violence: «Let us mark it well: here the earth is called the highest of gods. Violence-doing, the human being disturbs the calm of growth, the nourishing and enduring of the tireless one» $(2000,164) .{ }^{5}$ In other words: Earth, the highest goddess, surrenders in the face of man's violence, which disturbs its peace and quiet to gain sustenance for the human species. Heidegger highlights precisely once again the violence implicit in humankind's dominion over the ancestral goddess. However, in an influential lecture entitled «Building Dwelling Thinking», included in Poetry, Language, Thought, pregnant with echoes cherished by Ecocriticism, Heidegger meditates upon the relationship between building and dwelling in memorable words that are worth quoting in full. Even if man exerts violence on the earth and its creatures, Heidegger equates building with dwelling and with care:

Now, what does bauen, to build, mean? The Old High German word for building, buan, means to dwell. This signifies to remain, to stay in a place. The proper meaning of the verb bauen, namely, to dwell, has been lost to us. [...] The way in which you are and I am, the manner in which we humans are on the earth, is buan, dwelling. To be a human being means to be on the earth as a mortal. It means to dwell. The old word bauen, which says that man is insofar as he dwells, this word bauen, however, also means at the same time to cherish and protect, to preserve and care for, specifically to till the soil, to cultivate the vine. Such building only takes care - it tends the growth that ripens into its fruit of its own accord. (1971, 146-147)

\section{In Praise of Human Creativity and Progress}

In the stanzas that constitute the core of the chorus, Sophocles praises human ingenuity and perseverance as the true basis of the progressive achievements of humankind and the devel-

5 Heidegger's original German reads as follows: «Beachten wir es wohl: die Erde heißt die höchste der Götter. Gewalt-tätig stört der Mensch die Ruhe des Wachstums, das Nähren und Austragen der Mühelosen» (1983, 163). 
opment of successive civilisations on Earth. Beneath the verbal surface of these verse lines is the notion that progress in the arts and sciences is ultimately a progress dependent on human effort and not on divine revelation. So by ascribing scientific and technical progress to human ingenuity alone, Sophocles is embracing a conception of knowledge as progressing steadily and gradually from small beginnings, through humans' own powers of discovery and invention. In fact, according to W. K. C. Guthrie, two different views of human development were embraced in ancient Greece:

Two conflicting views of human development were current in classical Greece. The first, that it represented a degeneration from an original 'golden race' in the distant past, was given its standard form by Hesiod (Works, $109 \mathrm{ff}$.). These early men were both good in themselves and happy in their circumstances, for nature produced its fruits in abundance with no toil on their part. According to the second, more realistic view the earliest men were ignorant and brutal in character, and at the mercy of wild beasts and all the forces of a hostile nature. Gradually learning by bitter experience, they improved both morally and in their conditions of life, as one by one the arts of building, weaving, domestication of animals, agriculture, and above all of combining in communities for mutual protection, were discovered and mastered. This less mythical version rapidly gained aground at the expense of the other during the fifth century. $(1965,399-400)^{6}$

6 According to Guthrie, an extant fragment by Xenophanes gives the same idea in a nutshell: «Fragment 18 of Xenophanes («The gods did not reveal to men all things in the beginning, but in course of time, by searching, they find out better.»), where the emphasis is on personal search, on the need for time, which makes this «the first statement in extant Greek literature of the idea of progress in the arts and sciences, a progress dependent on human effort and not - or at least not primarily - on divine revelation. It foreshadows the praise of human ingenuity and perseverance in Sophocles' Antigone (332 ff.)» (1965, 399-400). 
Thus, the second stanza of «Of the Snaring of Birds» presents a view of «man the tactician». By his sly inventions, man manages to master the art of hunting and of the domestication of air, sea and land animals, in much the same way he manages to domesticate the land through cultivation. There is no living creature in this world that will not eventually fall prey to his nets and yokes, for man is a creative and resourceful being. The birds of the air, the fish of the deep sea, the goats of the mountain, horses and bulls: ${ }^{7}$ all of them are at the mercy of ingenious man, who controls all living creatures from his position at the very top of creation. The texture of Bringhurst's translation of the original Greek text can be best felt in verse lines of utter simplicity like these, in which the reader's mind is invited to dance to the rhythm of Pound's melopoeia and logopoeia: ${ }^{8}$

Birds' minds climb the air, yet he snares them, and creatures of the field.

These

7 As Heidegger puts it, «[Die Gegenstrophe] nennt den Vogelschwarm in den Lüften, das Getier im Wasser, Stier und Roß in den Bergen. [...] Als Lebendiges ist es dem Walten des Meeres und der Erde eingefügt. In dieses in sich rollende Leben, im eigenen Kreis und Gefüge und Grund ungewöhnlich, dahinein wirft der Mensch seine Schlingen und Netze, dieses reißt er aus seiner Ordnung und sperrt es in seine Gehege und Pferche ein und zwingt es unter die Joche. Dort: Ausbruch und Umbruch, hier: Einfang und Niederzwang» (1983, 163-164). [«[The antistrophe] names the flocks of birds in the air, the animal life in the water, the bull and stallion in the mountains. [...] As a living thing, it is fitted into the sway of the sea and the earth. Into this life that revolves within itself, its ambit, structure, and ground unfamiliar to them, humans cast their snares and nets; they tear this life away from its own order, enclose it in their paddocks and pens, and force it beneath the yoke. In one arena, breaking forth and breaking up; in the other, capturing and subjugating» (164-165).]

8 Pound drew a distinction between melopoeia (the music inherent in words), phanopoeia (words as images) and logopeia (ideas embedded in words, or the dance of the intellect among words). In «How to Read» (1928), he writes: «There are three 'kinds of poetry': MELOPOEIA, wherein the words are charged, over and above their plain meaning, with some musical property, which directs the bearing or trend of that meaning. PHANOPOEIA, which is a casting of images upon the visual imagination. LOGOPOEIA, 'the dance of the intellect among words'» $(1968,25)$. 
and the flocks

of the deep sea. He unfurls

his folded nets for their funeral shrouds.

Man the tactician.

So, as you see, by his sly

inventions he masters

his betters: the deep-throated

goat of the mountain,

and horses. His yokes ride the necks

of the tireless bulls who once haunted these hills. $(2005,39)$

The third stanza of «Of the Snaring of Birds» is a moving meditation on several other accomplishments on the part of human beings: speech (the art of expressing ideas, emotions and feelings by means of words), politics (the art of living together harmoniously for mutual enrichment) and architecture (the art of building houses to protect themselves from exposure to hostile elements). This stanza is pregnant with a wealth of meaning that is worth analysing in detail. Speech is what distinguishes human beings from all other beings in the world; humans' ability to convey to others through words what they think and feel is a recognisably human attribute. This does not mean, of course, that only humans have a monopoly on meaning. Every single thing in this universe seeks to mean something and speaks a language of its own, for we live in a polyphonic Earth. However, words are a purely human invention: the breath emanating from humans' lungs is endowed with a distinct meaning that is easily recognisable through convention by members belonging to the same speech community. In Bringhurst's rendering of Sophocles' original Greek, the emphasis is laid precisely on the oral dimension of speech with the utmost linguistic economy: "And the sounds in his own throat / gather the breezes that rise in his mind» (2005: 41). Words are literally «sounds» born in the throat that allow humans to give voice to the «breezes» (ideas and feelings) in their minds. These sounds are not unintelligible 
noises, but distinct combinations of sounds that are easily recognisable to the human ear. Speech is, thus, the true singularity of humankind: language (in singular) is the most ambitious creation of the human spirit and languages (in plural) are the true repositories of human memory and knowledge. Nothing is left behind en route, for nothing is ever truly lost. In a classic like Language (1921), Edward Sapir already pointed out that «Language is the most massive and inclusive art we know, a mountainous and anonymous work of unconscious generations» (220). What makes human progress possible is precisely language - an inexorably creative power and the infinite treasure-house of all the words, thoughts, ideas and feelings that humans shape in their minds.

The ingenuity and perseverance of humans know of no limits. Humans have also mastered the art of living together in harmony, for man «has learned how to sit on committees» (Bringhurst, 2005, 41) and devised codes of laws and rules to arbitrate the functioning of society. Centuries ago, Aristotle claimed in his

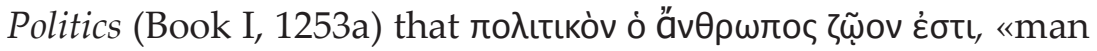
is a political animal» $(1932,10)$, which means that man is bound to live with other men and women, otherwise he would lead a solitary and miserable existence away from all human company. Needless to say, in Sophocles' time, the polis or city-state was a notion central to the ancient Greeks' minds. It was a right and a duty to stand up to the demands of one's city-state, «to add beauty and strength» (Bringhurst, 2005, 41) to the polis, to stand high in it in order to honour oneself and one's fellow citizens. Furthermore, in another more pragmatic realm, humans have also mastered the art of building «houses and barns / against blizzards and gales» (Bringhurst, 2005, 41). Amid a hostile world, humans have learned to seek the warmth and protection of houses, so as not to be at the mercy of the elements and to protect their vulnerable bodies from excessive heat and cold. Finally, the closing lines of the third stanza offer a brief though intense meditation on a simple fact: that humans have mastered speech as well as 
politics and the art of building houses is an inevitable part of the glory and splendour inherent in humankind, and yet misery is also somehow inescapable. There is nothing humans cannot attain, not a goal out of their reach, such is their perseverance and their capacity to accomplish things. However, humans are also capable of the worst things imaginable:

He manages all and yet manages nothing. Nothing is closed to the reach of his will, and yet he has found no road out of hell. His fate, we all know, is precisely what he has never outwitted. $(2005,41)$

By «fate» Bringhurst means death. So there is only one thing that humans have not managed to outwit, and that is death. There is nothing they can do to prevent it from happening. In this respect, Heidegger says that death is the inescapable end, boundary or frontier: «There is only one thing against which all violence-doing directly shatters. That is death. It is an end beyond all completion, a limit beyond limits. Here there is no breaking forth and breaking up, no capturing and subjugating» (2000, 121). ${ }^{9}$ Death is the last of all possible limits, claims the philosopher. Death is also a mystery, possibly the greatest of all. The idea of an uncanny vacuum opening its arms wide open towards us when we leave this life on Earth is simply scary. Death has accompanied humans since the beginning of their odyssey on this planet; it is the inevitable shadow walking by one's side from the very cradle to the very grave. Death is also present in many of Bringhurst's early poems: for instance, the dramatic monologues Deuteronomy (1974), Jacob Singing (1977) and The

9 The original reads thus: «Nur an einem scheitert alle Gewalt-tätigkeit unmittelbar. Das ist der Tod. Er über-endet alle Vollendung, er über-grenzt alle Grenzen. Hier gibt es nicht Ausbruch und Umbruch, nicht Einfang und Niederzwang» (1983, 167). 
Stonecutter's Horses (1979) are all concerned with old men preparing to die. In the recreation of Petrarch's last will and testament in The Stonecutter's Horses, the first movement of the poem dwells on the need to think about death deeply: «thinking of death can never be / wasted thinking» $(1979,3)$ for «A man carries his death with him / everywhere, waiting, but seldom thinking / of waiting. Death is uncommonly like the soul» $(1979,3)$. In general, in Bringhurst's poems death is seen as a natural and inevitable part of life. It could not be otherwise when analysed by a sage's mind which stays calm and serene in the face of what is inescapable.

Throughout the history of Western Philosophy, innumerable authors and thinkers have meditated upon death. In the lecture «The Thing», following in the steps of Plato, who has Socrates affirm in his first dialogue that to philosophise is to learn how to die, Heidegger himself acknowledges that death is precisely the ultimate frontier and what makes us truly human:

The mortals are human beings. They are called mortals because they can die. To die means to be capable of death as death. Only man dies. The animal perishes. It has death neither ahead of itself nor behind it. Death is the shrine of Nothing, that is, of that which in every respect is never something that merely exists, but which nevertheless presences, even as the mystery of Being itself. As the shrine of Nothing, death is the shelter of Being. We now call mortals mortals - not because their earthly life comes to an end, but because they are capable of death as death. Mortals are who they are, as mortals, present in the shelter of Being. They are the presencing relation to Being as Being. $(1971,176)$

Miguel de Unamuno's thought on death might also be pertinent at this point. Even though in The Tragic Sense of Life he admitted that he needed God to make sense of life and that he could not tolerate the idea of there being no afterlife, he exalted humans' insatiable desire for life as the greatest secret of human 
life. Confronted with the mystery of death, Unamuno speaks lucidly about the supreme secret of life in one of his philosophical meditations, entitled «The Secret of Life»:

And the secret of human life, the universal secret, the root secret from which all other secrets spring, is the longing for more life, the furious and insatiable desire to be everything else without ever ceasing to be ourselves, to take possession of the entire universe without letting the universe take possession of us and absorb us; it is the desire to be someone else without ceasing to be myself, and continue being myself at the same time I am someone else... (1974, $200)^{10}$

In the Spanish philosopher's conceptualisation of life and death, desire is the force driving humans' lives: the desire to live longer seems to cancel death as the ultimate end or boundary. The imperative to embrace otherness and to be everything and everyone else in the universe is reminiscent of Sophocles' view that man is tò $\delta \varepsilon$ ivótatov, the strangest thing on Earth, characterised by an unappeasable longing for knowledge and dominion over the world. If curiosity and wonder are the mothers of science and philosophy as well as the forces driving the succession of civilisations upon Earth, the longing for more life, which Unamuno defines as being the root secret of human life, is the core trait of humankind. No one wants to die - at least not without feeling that they have led an authentic life and that their potential has been realized to the full. Goethe is known to have asked for noch mehr Licht - more light, more life - on his deathbed.

10 Unamuno's original text reads thus: «Y el secreto de la vida humana, el general, el secreto raíz de que todos los demás brotan, es el ansia de más vida, es el furioso e insaciable anhelo de ser todo lo demás sin dejar de ser nosotros mismos, de adueñarnos del universo entero sin que el universo se adueñe de nosotros y nos absorba; es el deseo de ser otro sin dejar de ser yo, y seguir siendo yo siendo a la vez otro» $(2007,932)$. 


\section{Honourable Citizens of the Polis}

The closing stanza of Bringhurst's rendering of Sophocles' chorus is not only a well-wrought meditation on wisdom and knowledge, but also a celebration of order and harmony, and a reminder of the citizen's duties in the context of the Greek polis. The fourth stanza of «Of the Snaring of Birds», which has been extensively revised from one textual incarnation to the next, reads as follows in The Old in Their Knowing:

Wise, yes - or ingenious.

More knowledge than hope in his hand, and evil comes out of it sometimes, and sometimes he creeps toward nobility. Warped on the earth's loom and dyed in the thought of the gods, a man should add beauty and strength to his city. But he is no citizen whatsoever if he is tied to the ugly by fear or by pride or by greed or by love of disorder or order.

May no one who does not still wonder what he is and what he does come in and sit at my fireside. ${ }^{11}(2005,41)$

Two little movements for the soul are discernible in these verse lines. In the first movement, man is described as being wise or ingenious, but we are well aware that wisdom is not exactly the same as ingenuity. True wisdom is hard to attain; it is not the same as knowledge or erudition. Sages of all times like the ones whose

11 In The Beauty of the Weapons version, the closing lines read like this: «if he is tied to the ugly by love of adventure. / May no one who will not wonder what he is and does / suddenly arrive at my fireside» $(1982,68)$. In The Calling, they read thus: «if he is tied to the ugly by fear / or by greed or by love of disorder. May no one / who will not wonder what he is and what he does / suddenly arrive at my fireside» $(1995,65)$. The last verse line reads «suddenly arrive at my fireside» $(2009,53)$ in the version of the poem collected in Selected Poems. 
company Bringhurst has sought throughout his life (and whose thinking he has sought to capture in his poetry) have a clarity of mind that is precious and rare to find among common human beings. If they become wise, it is because their sharp minds are able to go beyond the surface texture of things and to penetrate a core of irreducible meaning in reality. At any rate, the sudden revelation or epiphany concerning the ultimate essence of reality is not a gift given to all human beings. To Bringhurst, truth is not what one looks for on purpose, but something that unveils itself when least expected. Truth unveils itself to inquisitively quiet and sharply luminous minds like those of the Pre-Socratics.

And yet, as Aristotle put it about 24 centuries ago in the opening lines of his Metaphysics, every human being wants to know and to understand. ${ }^{12}$ The desire to know is a basic necessity which resembles other basic necessities such as the universal need to feed and clothe oneself. Back in ancient Greece, Pla-

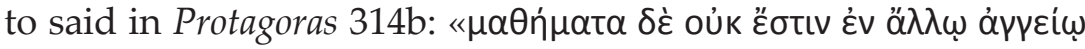

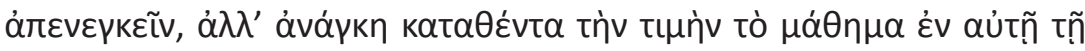

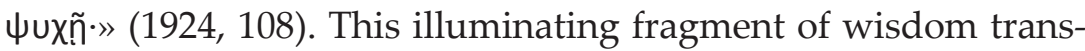
lates into English like this: «You can't carry knowledge away in a sack; when you've paid what knowledge costs, it is, unavoidably, part of your very own life» (Bringhurst, 2011, 35). Centuries later, Northrop Frye observed something similar in his book The Stubborn Structure. In the opening lines of the essay «The Instruments of Mental Production», which remains a powerful statement on the nature and value of human knowledge, the critic dwells precisely on what knowledge is most worth having. With astonishing conviction, Frye affirms that «the knowledge of most worth, whatever it may be, is not something one has: it is something one is» $(1970,1)$. He adds: «The only knowledge that is worthwhile

12 These are the opening lines of Aristotle's Metaphysics: «All men by nature desire to know. An indication of this is the delight we take in our senses; for even apart from their usefulness they are loved for themselves; and above all others the sense of sight.» See The Complete Works of Aristotle. The Revised Oxford Translation, Vol. 2, p. 1552. The original translation is by W. D. Ross and was published by Clarendon Press, Oxford, in 1924. 
is the knowledge that leads to wisdom, for knowledge without wisdom is a body without life» $(1970,15)$. The crucial point Frye makes is that knowledge is not something we own; we are what we know. Knowing, not owning: this is what understanding reality is all about. This is an illuminating insight into the ultimate sense of knowledge and the universal human vocation for learning. The knowledge of greatest worth is that which we have possibly become in an unconscious manner, without our noticing it.

Humankind's ultimate vocation is learning, or knowledge as a most powerful tool to take dominion over the world, affirms Sophocles, but the Greek playwright is also well aware that human beings are both good and evil. Holding more knowledge than hope in their hands, humans are endowed with a natural tendency towards evil and nobility. This is one of the fundamental paradoxes inherent in the human condition: that humans should be able to accomplish the most sublime feats and that, at the same time, they should be capable of committing the most atrocious crimes as well is a mystery indeed. In the second movement of the last stanza, the emphasis is on man as exemplary citizen of the polis. A man of honour does his best to stand high in his city and «add beauty and strength» $(2005,41)$ to his polis. If he happens to be on the side of ugliness for whatever reason, he ceases to be a citizen of any worth. The Greek mind rightly despises chaos and loves order instead. At the end of the poem, the voice speaking these lines says that nobody is welcome to sit by his fireside if they do not still wonder what they are and what they do. A sense of wonder in the face of the mystery that oneself is is an essential prerequisite if they are to be admitted in his company, in his home, as symbolised by the hearth or fireside.

\section{Tradition and the Nutriment of Poetry}

"Of the Snaring of Birds» is an accomplished version of the chorus from Sophocles' Antigone (lines 332-375) which Bringhurst conceives of as a homage to Martin Heidegger. The German phi- 
losopher's sharp philosophical reading of the Greek text in his Introduction to Metaphysics appears to be the perfect companion to Sophocles' chorus in that it discloses nuances of meaning that are of paramount importance in the history of the Western conceptualisation of humankind. To Heidegger's mind, man is the strangest thing on Earth, capable of the most sublime and the most terrible feats one can possibly think of. It is by building that humans come to dwell on Earth, and by dwelling on Earth they come to care for it. Man the tactician is capable of domesticating the surrounding natural world and its creatures in many different ways, and yet there is an ultimate frontier he cannot avoid, which is death. Even if man's endless sagacity has devised agriculture, language, architecture and politics in his compulsion to conquer the earth and the sea, death turns out to be the inevitable fate he cannot outwit. However, upon closer inspection, it is precisely death that makes mortals truly human.

In translating Sophocles' chorus, an ancient text dating back to the first millennium $\mathrm{BCE}$, Bringhurst is making a powerful statement on his own poetics and on his personal literary canon. Bringhurst spends much of his time in the company of ancestors, poets and philosophers from different literary traditions, Western and Eastern alike. Breathing and walking by their side, he learns that literature builds on more literature, that there is no pre-existing order for new poems unless that of previous poems, and that, as T. S. Eliot rightly pointed out back in 1919 in his seminal «Tradition and the Individual Talent», the genuine blood of great poetry is tradition. Thus, he finds the nutriment he needs to compose his own poetry in the work of his intellectual ancestors, and he aims to contribute lasting poetry to an Eliotian plurilingual Weltliteratur which is a gigantic work in progress where nothing is ever lost en route.

Salvaged texts from the past like Sophocles' chorus still talk to contemporary readers precisely because they are capable of traversing eons of space and time to instruct and to move readers' sensibilities. Most importantly, ancient texts like the chorus 
from Antigone unveil universals pertaining to humankind in its entirety. They are tattered fragments of wisdom, as it were. What Bringhurst finds in the Greek master is a powerful meditation on human nature that still moves 21st-century readers, precisely because Sophocles is a classic author, one who is capable of transcending temporal and geographical barriers. Italian novelist and literary critic Italo Calvino is right to recommend that we read the classics time and again, as there is an endless spiritual sustenance to be gained from their wisdom. As he points out in Why Read the Classics?, "The classics are books which exercise a particular influence, both when they imprint themselves on our imagination as unforgettable, and when they hide in the layers of memory disguised as the individual's or the collective unconscious» $(2000,4)$.

In Sophocles' text, Bringhurst finds a jewel condensing a wealth of meaning that is worth translating into contemporary English to the benefit of readers. Thus, «Of the Snaring of Birds» tessellates a handful of resonant and luminous words rescued from a distant past which shed light on the human condition. What Bringhurst accomplishes in his poem is a formidable version of Sophocles' meditation when compared to the plain prose translation of non-poets and philologists. He succeeds in making a 2,400-year-old poem brand new for contemporary readers, making them experience what remains the same in spite of the passage of time, while using the poetic conventions and language of the 21st century. What is gained in translation is beyond words. What he finds in Sophocles is much more than a translation challenge or exercise in intellectual gymnastics. The Antigone chorus is a jewel-like meditation on what makes us genuinely humans; it is also a gift to those postmodern readers who are still willing to listen to the old in their knowing.

\section{References}

Aristotle (1932) Politics. Translated by H. Rackham, Loeb Classical Library, Cambridge, MA, Harvard University Press. 
(1984) The Complete Works of Aristotle. The Revised Oxford Translation. Vol. 2., ed. Jonathan Barnes, Princeton, New Jersey, Princeton University Press.

Bringhurst, R. (1973) Cadastre, Bloomington, Indiana, Kanchenjunga Press.

Editions.

(1979) The Stonecutter's Horses, Vancouver, Standard

(1982) The Beauty of the Weapons: Selected Poems 19721982, Toronto, McClelland and Stewart.

(1986) Pieces of Map, Pieces of Music, Toronto, McClelland and Stewart.

(1995) The Calling: Selected Poems 1970-1995, Toronto, McClelland \& Stewart.

Koch.

(2005) The Old in Their Knowing. Berkeley: Editions

(2007) Everywhere Being Is Dancing: Twenty Pieces of Thinking, Kentville, Nova Scotia, Gaspereau Press.

(2009) Selected Poems, Kentville, Nova Scotia, Gaspereau Press.

(2011) What Is Reading for? Rochester, New York, Cary Graphic Arts Press.

Calvino, I. (2000) Why Read the Classics?, translated from the Italian by Martin McLaughlin, New York, Vintage Books.

Eliot, T. S. (1956) On Poetry and Poets, London, Faber and Faber Ltd.

Frye, N. (1964) The Educated Imagination, Bloomington and Indianapolis, Indiana University Press.

(1970) The Stubborn Structure. Essays on Criticism and Society, London and New York, Methuen.

Guthrie, W. K. C. (1965) A History of Greek Philosophy. II: The Presocratic Tradition from Parmenides to Democritus, Cambridge, Cambridge University Press.

Heidegger, M. (1959) Unterwegs zur Sprache, Frankfurt am Main: Vittorio Klostermann. 
(1971) Poetry, Language, Thought, translated by Albert Hofstadter, New York, Harper \& Row.

(1983) Einführung in die Metaphysik (Band 40 der Gesamtausgabe), Frankfurt am Main, Vittorio Klostermann.

(2000) Introduction to Metaphysics, new translation by Gregory Fried and Richard Polt, New Haven \& London, Yale University Press.

Lillard, C. (1983) «Review of Tzuhalem's Mountain and The Beauty of the Weapons», The Reader 2.2, 1-4.

Plato (1924) Laches. Protagoras. Meno. Euthydemus, trans. W. R. M. Lamb, The Loeb Classical Library, Cambridge, MA, Harvard University Press.

Pound, E. (1968) Literary Essays of Ezra Pound, ed. by T. S. Eliot, New York, New Directions.

Rigaud, T. (2002) Translating Haida Poetry: An Interview with Robert Bringhurst, Vancouver \& Toronto, Douglas \& McIntyre.

Ruthven, K. K. (1969) A Guide to Ezra Pound's Personae (1926), Berkeley, Los Angeles, London, University of California Press.

SAPIR, E. (1921) Language: An Introduction to the Study of Speech, New York, Harcourt / Brace.

Sophocles (1891) The Antigone of Sophocles, edited with introduction and notes by Richard C. Jebb, Cambridge, Cambridge University Press.

(1994) Antigone. The Women of Trachis. Philoctetes. Oedipus at Colonus, edited and translated by Hugh Lloyd-Jones, Cambridge, Massachusetts, Harvard University Press.

Unamuno, M. (1974) Selected Works of Miguel de Unamuno. Volume 5: The Agony of Christianity and Essays on Faith, translated by Anthony Kerrigan, Bollingen Series, LXXXV, Princeton, N. J. Princeton University Press.

(2007) Obras completas de Miguel de Unamuno. Volumen VIII: Ensayos, edición de Ricardo Senabre, Madrid, Biblioteca Castro. 
